\title{
Zastosowanie metody biocenotycznej oceny drzew w parku „Willa Mindic" (Mołdawia) na potrzeby wykonania projektu koncepcyjnego zagospodarowania terenu - studium przypadku
}

\section{Lidia Ozimkowska, Jerzy Wojtatowicz}

\section{STRESZCZENIE}

W artykule przedstawiono zastosowanie metody oceny biocenotycznej drzew w parku „Willa Mindic" (Mołdawia). Przeprowadzając inwentaryzację uwzględniano wstępne decyzje projektowe, które także miały wpływ na określenie wartości drzew. Rozszerzając waloryzację roślin o badanie stanu zdrowotnego, w tym bezpieczeństwa dla ludzi, uzyskano wyniki, które służyły do wykonania projektu. Wytypowano miejsca, które bez względu na warunki muszą zapewnić bezpieczne przebywanie, fragmenty terenu, na których zwiedzanie parku jest ograniczone oraz te, na których ze względu na wysokie wartości biocenotyczne, $\mathrm{w}$ tym ochronę miejsc lęgu i rozrodu zwierząt, nie przewiduje się ciagów komunikacyjnych i miejsc wypoczynkowych. Na podstawie badań wskazano obszary o wyjątkowym znaczeniu dla zwierząt oraz wykonano projekt koncepcyjny zagospodarowania terenu uwzględniający potrzeby wypoczynkowe ludzi.

Słowa kluczowe: architektura krajobrazu, dendrologia, wartości biocenotyczne drzew, powiązania przyrodnicze

\section{Wprowadzenie}

W numerach 18. z 2016 r. oraz 32. z 2020 r. periodyku naukowego „MAZOWSZE Studia Regionalne" ukazały się dwie publikacje, które są związane z niniejszym artykułem. Pierwsza z nich pt. Zespót dworsko-parkowy "Willa Mindic” jako szczególny element w krajobrazie i przemiany jego struktury jako znaków czasu dotyczy historycznego parku położonego w Mołdawii. W drugim artykule pt. Metoda waloryzacji drzew ze względu na ich wartości biocenotyczne opisano metodę biocenotycznej waloryzacji drzew, która może być wykonywana w ramach prac przedprojektowych obiektów przyrodniczych o głównej funkcji wypoczynkowej. W zaprezentowanej metodzie wyróżniono trzy kategorie oceny wartości biocenotycznej drzewa, które wynikają z: 1) cech osobniczych, 2) powiązań z najbliższym otoczeniem oraz położenia w parku i 3) umiejscowienia w odniesieniu do ekosystemów poza parkiem. Na podstawie punktacji można zakwalifikować drzewo do jednej z grup określonej wartości biocenotycz- 
nej. Metodę tę przedstawiono w dwóch wariantach. W każdym podano kryteria oceny drzew $\mathrm{w}$ formie opisowej i liczbowej. Wariant oceny w skali trzystopniowej ma zastosowanie w klasycznych opracowaniach o ograniczonym czasie realizacji projektu. Wariant oceny w skali pięciostopniowej adekwatny jest dla wielokierunkowych badań terenu, prowadzonych przez specjalistów różnych dziedzin dotyczących walorów przyrodniczych i kulturowych krajobrazu. W tym przypadku prace powinny być wykonywane dwustopniowo. Na pierwszym etapie każdy ze specjalistów ocenia składniki lub cechy krajobrazu w zakresie swojej specjalizacji. W drugim etapie wykonywane sa prace przez cały zespół z udziałem architekta krajobrazu. Przeprowadza się syntezę wszystkich wyników, z której wnioski służą do sporządzenia wytycznych do projektu zagospodarowania obiektu architektury krajobrazu.

W 2014 r. na zlecenie Polskiego Ministerstwa Kultury, Fundacja Dziedzictwa Kulturowego - polska organizacja społeczna zajmująca się ochroną zabytków, wspólnie ze strona mołdawska ${ }^{1}$ zorganizowała wyjazdy specjalistów różnych dziedzin, w tym geodetów, konserwatorów sztuki, architektów, architektów krajobrazu. Autorzy niniejszego artykułu byli odpowiedzialni za koordynację wszelkich badań przedprojektowych, ich analizę i syntezę, a także przygotowanie koncepcji zagospodarowania terenu uwzględniającej własne badania przyrodnicze oraz wytyczne wynikające z badań historycznych [Michałowski, Werner, 2014] i budowlano-architektonicznych prowadzonych przez Politechnikę w Kiszyniowie. Wraz ze studentami Architektury Krajobrazu WSEiZ² Robertem Jancelewiczem i Andrzejem Szczepanikiem wykonano opracowanie dotyczace inwentaryzacji dendrologicznej i gospodarki drzewostanem parku uwzględniając waloryzację drzew metodą biocenotyczną. Opracowania te posłużyły do wykonania projektu koncepcyjnego zagospodarowania terenu „Willa Mindic".

\section{Cel i zakres}

Celem artykułu jest ukazanie problemów, które wystapiły przy zastosowaniu metody biocenotycznej oceny drzew $\mathrm{w}$ historycznym parku. $\mathrm{W}$ ramach zakresu pracy przytoczono pojęcie roślin biocenotycznych, wyjaśniono zasady kategoryzacji drzew w zastosowanej metodzie, opisano specyfikę terenu, który w istotny sposób wpływał na przeprowadzone badania, przybliżono problemy występujące przy zastosowaniu metody do wykonania projektu, zaprezentowano projekt koncepcyjny zagospodarowania terenu. Uzupełniającym celem artykułu jest popularyzacja opracowanego przez autorów sposobu biocenotycznej oceny drzew.

\footnotetext{
${ }^{1}$ Pierwsze prace dotyczace rewaloryzacji zabytkowego założenia, w których uczestniczyła strona polska rozpoczęły się już w 2002 r. Przedstawiciel Ministerstwa Ekologii ze strony Mołdawskiej i dyrektor Zarządu Ochrony i Konserwacji Zespołów Pałacowo-Ogrodowych Muzeum Narodowego, ze strony Polskiej podpisali porozumienie w sprawie odbudowy parku Mindyk. W 2012 r. zespół ekspertów z Polski (doc. dr Andrzej Michałowski, mgr historii sztuki Barbara Werner, mgr inż. arch. Kinga Dujanowicz) był w Mołdawii w ramach rozeznania stanu faktycznego założenia „Willa Mindic”.

${ }^{2}$ Wyższa Szkoła Ekologii i Zarządzania w Warszawie
} 


\section{Pojęcie roślin biocenotycznych w odniesieniu do metody ich waloryzacji}

Jak podano w artykule opisującym metodę biocenotycznej waloryzacji drzew [MAZOWSZE Studia Regionalne 32 / 2020] „za drzewa, krzewy i inne rośliny biocenotyczne, uznaje się te, które mają szczególne znaczenie dla życia i rozwoju innych organizmów. Rośliny te moga być siedliskiem życia innych roślin, grzybów i porostów, a także dostarczać zwierzętom pokarmu, schronienia lub być wykorzystywane jako miejsca rozrodu czy lęgu. Wartość tych roślin wynika zarówno z biologicznych cech gatunku, właściwości osobniczych, jak i położenia w krajobrazie. Istotne jest zarówno najbliższe sąsiedztwo, jak i umiejscowienie w odniesieniu do sąsiadujących ekosystemów. (...) Drzewa, krzewy i pnącza biocenotyczne moga zaspokajać jedną potrzebę życiową innych gatunków w ciagu krótkiego okresu lub wiele potrzeb, nawet przez wiele lat. Biorąc pod uwagę wartość biocenotyczną drzewa nie ocenia się wysoko jego przydatności dla jednego, nawet bardzo szczególnego organizmu, który jest zagrożony wyginięciem, co mogłoby być istotą oceny drzewa z punktu widzenia ochrony przyrody. Najważniejsze jest znaczenie drzewa w jego siedlisku." Dla ochrony przyrody, jako pojęcia szerszego, duże znaczenie maja pomniki przyrody, gatunki chronione, rzadkie, zagrożone wyginięciem. Kwalifikuje się je do drzew o szczególnym znaczeniu, które, jeśli tworzą warunki do życia i rozwoju wielu innych gatunków, powinny być klasyfikowane także jako drzewa biocenotyczne. Nie znaczy to jednak, że wysoko oceniane będa drzewa ekspansywne degradujacce ekosystem lub te, które sprzyjają rozwojowi gatunków wpływających na obniżenie wartości całego zbiorowiska, pomimo że ich oceniana w oderwaniu od otoczenia wartość mogłaby być określona jako wysoka.

Waloryzacja drzew metodą biocenotyczna, jako badanie jakościowe, nie daje możliwości wyciagnięcia porównawczych wniosków i przedstawienia ich np. w postaci liczbowej. Nie odpowiada na pytanie „ile drzew ma dane wartości” $\mathrm{i}$,jjak często występują rośliny biocenotyczne”, natomiast można przy jej zastosowaniu uzyskać odpowiedź na pytanie „jak ocenić przydatność drzewa dla flory i fauny” i „dlaczego zaliczamy drzewo do określonej grupy”. Wyników badań nie można generalizować, bowiem nie są reprezentatywne dla wszystkich obiektów architektury krajobrazu. Każdy rozpatrywany obiekt jest inny i z tych powodów opisana metoda może stanowić przykład postępowania, lecz przed jej zastosowaniem powinna być poddana krytycznej analizie, a czasami zmodyfikowana do konkretnej sytuacji. Nie ukazuje ona powszechności zjawiska występowania wartości biocenotycznych, a jedynie jego zróżnicowanie. $W$ badaniach może wystapić problem z kategoryzacja, szczególnie w poczatkowej fazie ich przeprowadzenia, zanim oceniający nie osiagnie pewnej wprawy. Wyniki takich badań niekoniecznie prowadzą do prostych konkluzji interpretacyjnych. Zachowanie wartości przyrodniczych czy kulturowych objętych ochroną prawną nie podlega dyskusji. Jednak wiele istniejących w parkach wartości, nawet tych dostrzegalnych, jak wartość biocenotyczna, nie doczekało się metod pozwalających na ich wyodrębnienie i uwzględnienie $\mathrm{w}$ dalszych etapach procesu projektowego. 


\section{Kategoryzacja drzew w metodzie oceny wartości biocenotycznej}

W zaprezentowanej metodzie wyróżniono trzy kategorie oceny wartości biocenotycznej drzewa. Dla kategoryzacji drzew istotne jest, że w opisywanej metodzie nie bierze się pod uwagę potencjalnej wartości biocenotycznej gatunku, lecz wartość poszczególnych egzemplarzy [Wojtatowicz 2010].

Pierwsza kategoria obejmuje cechy osobnicze drzewa. Wynikają one z wartości biologicznych (takich jak np. grubość kory i głębokość jej szczelin, obfite owocowanie czy zagęszczenia korony) sprzyjających życiu i rozwojowi rodzimych gatunków zwierząt, roślin i grzybów. Moga też mieć źródło w cechach nabytych, takich jak np. dziuple, występująca w koronie jemioła czy oplatające pień pnącze.

Druga kategoria ukazuje wartość biocenotyczną wynikającą nie tylko z cech osobniczych, ale i powiązań z najbliższym otoczeniem, czyli miejscami, w których poszczególne egzemplarze rosną. Nawet drzewa o bardzo podobnych cechach osobniczych mogą bardzo różnić się pod względem przydatności biocenotycznej. I tak jedno może rosnać z dala od ruchu ludzi i pojazdów, penetracji przez psy i koty, a drugie w miejscach o gęstej infrastrukturze, które są intensywnie użytkowane przy budynkach, wjazdach, drogach, placach zabaw itp.

Trzecia kategoria nawiązuje do usytuowania drzewa względem granicy parku i umiejscowienia w odniesieniu do ekosystemów poza parkiem. Podobnie jak w pierwszej i drugiej kategorii wartość drzewa wynika z cech osobniczych, ale i zależności od zagospodarowania terenu poza granicami parku, na które zarówno właściciel jak i projektant praktycznie nie mają wpływu. Jeden sąsiad może użytkować teren w sposób sprzyjający ochronie przyrody, a drugi prowadzić działania, które zubożają wartości przyrodnicze na jego terenie i w najbliższym otoczeniu. W tym względzie wartość osobnicza drzew może być podobna, a wartość dla biocenozy może być skrajnie różna. Tak więc, drzewo o porównywalnych cechach może być inaczej klasyfikowane w zależności od występowania innych czynników pozornie z nim nie związanych.

\section{Specyfika terenu badań}

\section{Uwarunkowania historyczne i prawne}

Założenie dworsko-parkowe z 1896 r. [Pasport Pamâtniki istorii i kultury SSSR] położone jest na terenie dzisiejszej Mołdawii, w północnej części Besarabii, między dwoma wioskami: Mindyc i Cotowa. Najbliżej położone miasto o nazwie Drochia znajduje się $25 \mathrm{~km}$ na południowy zachód. Ogólna powierzchnia całego terenu wynosi $17500 \mathrm{~m}^{2}$. Założycielem był Kajetan Oganowicz (Ohanowicz) (1791-1874) [Soloveva 2002] - polski szlachcic ormiańskiego pochodzenia [Theodorowicz 1925], który wybudował tu dwór w otoczeniu zieleni [Taras 1986], a następnie modernizował go przy współpracy z Alexandrem Bernardazzim (1831-1907), wybitnym besarabskim architektem. W wyniku tej współpracy powstała rezy- 
dencja w dolinie cieku wodnego z licznymi stawami, otoczona hektarami pól uprawnych. Park „Willa Mindic” został objęty ochroną w 1962 r. [Leontev 1967; Kravčuk 1972]. W 1975 r. Rada Ministrów Mołdawskiej Socjalistycznej Republiki Radzieckiej nadała mu status pomnika przyrody i do dnia dzisiejszego, pomimo wielu zaniedbań, cieszy się uwagą władz. W 1997 r. park został wpisany do rejestru zabytków Mołdawii [Monitorul Oficialal. Republicii Moldova, 18, 20 martie 1997, MOLDPRES]. „Willa Mindic” została filią Narodowego Muzeum Etnografii i Historii Przyrody w Kiszyniowie, powołano tam muzeum „Willa z parkiem Mindic" [www.dziedzictwo.org/Działalność/zespół-dworsko-parkowy-vila-mindic-moldawia]. W 1998 r. park został wpisany na listę Zabytków Architektury Krajobrazu.

\section{Uwarunkowania przyrodnicze}

Obszar przeznaczony do objęcia ochroną w 1975 r. wynosił 10 ha, był cenny ze względu na występowanie 35 rodzajów drzew i krzewów, w tym 20 egzotycznych, sady, stawy, budynek willi i kaplicy Ohanowiczów [Pasport Pamâtniki istorii $i$ kultury SSSR]. Stan ten nie zmienił się do lat 90. XX w. o czym świadczy wpis do tabeli pt. Historyczna charakterystyka $i$ stan wspótczesny starych parków Mołdawii [Dormidontowa w 1992 r.]. Badania inwentaryzacyjne w 2014 r. potwierdziły występowanie 30 rodzajów drzew i krzewów [Ozimkowska, Wojtatowicz, Szczepanik 2015]. Najliczniej występuja jesiony: pensylwański Fraxinus pennsylvanica, amerykański F. americana i wyniosły F. excelsior, w tym odmiana F. e. 'Elegantissima', klony: pospolity Acer platanoides, polny A. campestre i A. srebrzysty A. saccharinum, robinie Robinia pseudoacacia, wierzby: płaczaca Salix x sepulcralis 'Chrysocoma' i krucha S. fragilis, brzozy Betula, a z drzew iglastych świerki pospolite Picea abies i sosny czarne Pinus nigra. Z drzew owocowych jabłonie Malus, czereśnie, śliwy Prunus. Wyróżniająca jest aleja grabowa. Sporadycznie odnotowano morwę biała Morus alba, czeremchę późną Prunus serotina, oliwnik wąskolistny Eleagnus angustifolia, ajlant gruczołkowaty Ailanthus altissima. Park „Willa Mindic” w chwili obecnej posiada wyjątkowe wartości przyrodnicze: 70 sztuk wiekowych, ponad 100 letnich drzew, liczne, rzadkie gatunki owadów, a z płazów oprócz żab zielonych jest rzadkie, bogate stanowisko kumaka nizinnego Bombina bombina. Spotyka się tu, poza zielono ubarwionymi rzekotkami drzewnymi Hyla arboreta, egzemplarze o brunatnej, stalowej i beżowej barwie. W stawach parkowych żyje populacja żółwia błotnego Emys orbicularis. Istotne jest, że na terenie parku można zaobserwować rzadkie i atrakcyjne dla ludzi ptaki np. żołna zwyczajna Merops apiaster, zimorodek zwyczajny Alcedo atthis, dzięcioł zielonosiwy Picus canus, dzięciołek Dryobates minor, liczne ptaki szponiaste jak kobczyki, myszołowy, orły. Na uwagę zasługuja populacje takich ssaków jak łasica pospolita Mustela nivalis, suseł perełkowany Spermophilus suslicus, nietoperze. O niecodziennej wartości parku świadczy kilka dużych gniazd ptaków szponiastych, które w pewnych okresach zajmują kruki zwyczajne Corvus corax. Na podkreślenie zasługuje fakt, że park ten stanowi enklawę drzewostanu w krajobrazie rolniczym, w otoczeniu stawów. Wyjątkowe położenie, cechy biotopu (zwłaszcza klimatu lokalnego, nieprzeciętna urodzajność gleb czy układ hydrograficzny) oraz wieloletnie za- 
przestanie intensywnej eksploracji rekreacyjno-wypoczynkowej sprawiły, że obecnie teren ten ma nieprzeciętne walory przyrodnicze i jest ostoja wielu gatunków, w tym drapieżników polujących na gryzonie na okolicznych polach. Park jest też ważnym ogniwem na szlaku lokalnej migracji zwierząt.

\section{Uwarunkowania wypoczynkowe}

Powietrze w parku jest dobrze uwilgotnione, dzięki bliskości zbiorników wodnych i okapowi rozłożystych drzew ma obniżoną temperaturę latem. Drzewostan zatrzymuje rozwiewające się pyły oraz środki ochrony roślin uprawianych poza parkiem. Zimą temperatura jest wyższa, a wiatry mniej dokuczliwe. W okresie wegetacyjnym powietrze jest wysycone różnymi zapachami w porównaniu z jednorodnymi zapachami okolicznych upraw monokulturowych. Atrakcyjne jest lustro wody stawów oraz przepływające sezonowe potoki, które czasami dynamizują krajobraz.

Negatywnie odbiera się muliste dno, zapyloną wodę z tendencją do zarastania. Najwidoczniej ujawnia się to na południowym i południowo-zachodnich brzegach dużego zbiornika w miejscach, gdzie skarpy przechodzące w brzegi są silnie nasłonecznione, a woda jest płytka i ciepła. Z kolei płytkie wody z dużymi pokładami zawiesiny naniesionej z wawwozu wykazują mniejszą tendencję do zarastania, głównie w wyniku zacienienia i niższej temperatury. Podobne tendencje zarastania zbiornika występują w mniejszym stawie za grobla. Zbiornik, do którego wpływa sezonowy potok jest całkowicie zarośnięty z powodu erozji wodnej żyznych pól poza parkiem (czarnoziemy nalessowe), nawożonych nawozami mineralnymi oraz silnego nasłonecznienia. Stwarza on idealne warunki do rozwoju kumaka nizinnego, który występuje tu w niespotykanej liczbie. Nadmiar wody z tego zbiornika przepływa wąwozem do dużego rozwidlającego się stawu. Woda w sezonowym potoku zwraca uwagę, zwłaszcza w okresie dużych przepływów, gdy erozji podlega dno i brzegi, wyłaniaja się korzenie drzew rosnacych na zboczach, powstają wykroty. Zjawiska te można obserwować z mostku w alei grabowej (dawny szpaler) prowadzącej w kierunku kaplicy grobowej oraz ścieżki wzdłuż potoku. Grunty parkowe w okresie dużego uwilgotnienia sa śliskie, przylepiaja się do obuwia i sprawiaja trudności przy poruszaniu. W okresie suszy są silnie spękane i pylą. Ogromna wartość terenu dla osób wypoczywających wynika z obecności wielu atrakcyjnych gatunków zwierząt. Swoimi barwami, głosem lub wydawanymi dźwiękami i ruchem ożywiają krajobraz parku. Wśród zwierząt występuje tu wiele interesujacych gatunków: z owadów ważki i motyle, atrakcyjne dla potencjalnych wędkarzy ryby. Stwierdzono tu, oprócz typowo ubarwionych płazów, rzekotki w różnych barwach (beżowe, jasno i ciemno brązowe, stalowe i czarne), a także w przeważającej liczbie żaby zielone, których dolna strona grzbietu i kończyny tylne były w różnych odcieniach brązu i szarości. Kumak nizinny Bombina bombina w okresie rozrodu zwraca uwagę intensywnym dźwiękiem, który w takiej modulacji może być nie tylko zachwycajaccy, a nawet męczący. Żyje tu jaszczurka zwinka Lacerta agilis i cenna z punktu widzenia ochrony przyrody i wypoczynku duża po- 
pulacja żółwia błotnego Emys orbicularis, która sama w sobie mogłaby się stać celem podróży do tego miejsca. W maju 2015 r. obserwowano jednocześnie na skraju trzcinowiska 8 dorosłych osobników, a w szuwarze graniczącego z parkiem stawu rybnego jednocześnie 21 osobników. Wśród ptaków zwracają uwagę czaple białe Ardea alba i siwe A. cinerea, orły, orliki i kruki zwyczajne Corvus corax, charakteryzujące się barwą: żołny zwyczajne Merops apiaster, zimorodki zwyczajne Alcedo atthis, sójki zwyczajne Garrulus glandarius, śpiewem: słowiki szare Luscinia luscinia, kosy zwyczajne Turdus merula, kukułki zwyczajne Cuculus canorus, trzciniaki zwyczajne Acrocephalus arundinaceus, zięby zwyczajne Fringilla coelebs, makolagwy zwyczajne Linaria cannabina; dynamiką lotu: szybkie kobczyki zwyczajne Falco vespertinus, jeżyki zwyczajne Apus apus, jaskółki dymówki Hirundo rustica, zimorodki, żołny oraz szybujące myszołowy, orły i orliki. Drzewa o rozłożystych koronach dające dużo cienia, wśród których znajduja się polany, prześwity na lustra wody są nie tylko malownicze, ale zapewniają korzystny mikroklimat. Jest to duża wartość ze względu na usytuowanie parku wśród pól. Park daje możliwość podziwiania drzew o wyjątkowych wymiarach; wysokość niektórych topól kanadyjskich Populus x canadensis, jesionów wyniosłych Fraxinus excelsior, a nawet orzecha czarnego Juglans nigra dorasta do $23 \mathrm{~m}$, a średnica koron wierzb kruchych Salix fragilis przekracza szerokość $20 \mathrm{~m}$. Wiele gatunków grzybów tak umiejscowionych na drzewach, jak i w podłożu ma atrakcyjne owocniki. Park nie jest udostępniony dla ludzi, co przyczyniło się do wytworzenia i utrzymywania opisanych wyjątkowych wartości, które to kwalifikowały go do zastosowania w trakcie badań rozszerzonej - pięciostopniowej wersji metody biocenotycznej.

\section{Dostosowanie metody badań do specyfiki parku}

W związku z rozważaniem możliwości przystosowania terenu „Willa Mindic” na potrzeby międzynarodowego centrum pogranicza narodowościowego w Mołdawii [Dunajewicz, Werner 2013] lub muzealnego terenu oświatowo-dydaktycznego [Michałowski, Werner 2014], analizy przedprojektowe przeprowadzane były wielotorowo. Już pierwsza wizyta w parku uwidoczniła, że fragmenty struktury pierwotnej dawnego ogrodu Ohanowiczów, zawierającej ślady układu funkcjonalnego i kompozycyjnego, jak i pojedyncze elementy, które przetrwały do dzisiejszych czasów mają wysoką wartość przyrodniczą i kulturową. Było to impulsem do poszukiwań odpowiednich metod, które w jak największym stopniu zachowaja istniejące walory. Jedną z pilniejszych potrzeb było opracowanie metody pozwalającej na waloryzację drzew, ponieważ stwierdzono, że w drzewostanie występuje wiele gatunków odpowiadających za bogaty stan biocenozy. Umożliwiają one, poprzez swoje cechy osobnicze, życie wielu gatunkom i stanowią dla nich parasol ochronny (ryc. 1) ${ }^{3}$. Analiza wartości biocenotycznej drzew była jedną z wielu, która dopiero w odniesieniu do innych pozwoliła na wyodrębnienie obszarów o różnych funkcjach wiodących. Wartość biocenotyczną drzew

\footnotetext{
${ }^{3}$ Autorem wszystkich zdjęć zamieszczonych w artykule (ryc. 1-6) jest Jerzy Wojtatowicz.
} 
w tym przypadku określono nieco inaczej, niż to było opisane we wcześniejszym artykule, ponieważ traktowano teren nie jak typowy park rekreacyjny, a jak przeznaczony do wypoczynku obszar, który jednocześnie jest chroniony. Te ograniczenia spowodowały, że dużo większe znaczenie miało usytuowanie drzewa w parku. Czynnik ten w większości obiektów architektury krajobrazu powinien być traktowany na równi z innymi czynnikami takimi jak np. cechy osobnicze lub nabyte drzewa.
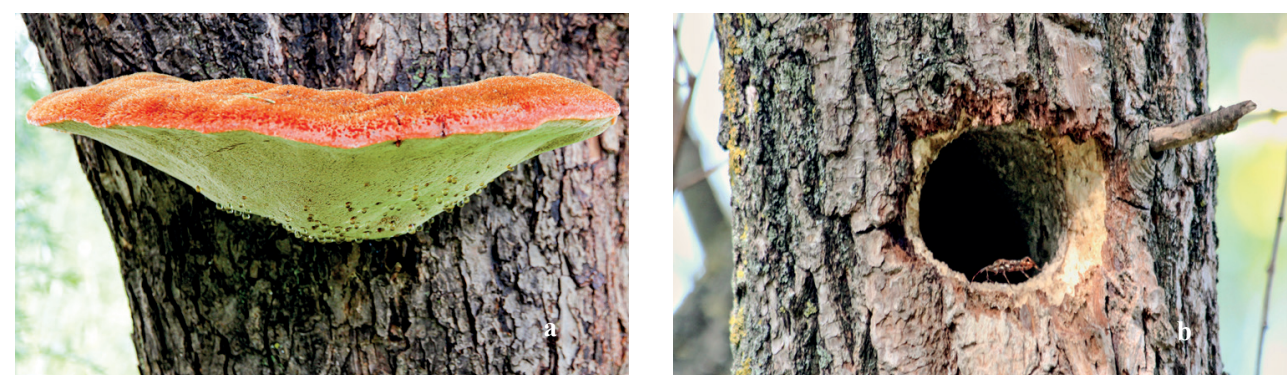

Ryc. 1. Drzewa o nabytej wartości biocenotycznej, jako miejsce życia organizmów żywych a) Drzewo jako miejsce życia grzybów, b) Drzewo z dziuplą wykorzystywaną przez owady po sezonie łęgowym ptaków

Uwzględniając priorytetową funkcję wypoczynkową obiektu przyjęto, że ochrona zasobów przyrodniczych i kulturowych powinna być traktowana w szczególny sposób w odniesieniu do pozostałych funkcji towarzyszących. Wynika to nie tylko z przepisów prawnych, ale i przewidywanej wzmożonej antropopresji po udostępnieniu obiektu do użytkowania. Wyniki opracowane na podstawie opisu metody biocenotycznej oceny drzew [patrz: „MAZOWSZE Studia Regionalne" 32/2020] uwidaczniają istniejące walory, a tylko w niewielkim zakresie wartości potencjalne, co spowodowało modyfikację zastosowanej metody. Wiadomo, że część drzew straci wartość na skutek naturalnych procesów, np. kompletnego rozkładu drewna lub działalności człowieka w trakcie kształtowania docelowej wizji projektanta. W ten sposób drzewa, które maja potencjał rozwojowy sprzyjający podwyższaniu wartości przyrodniczej oceniano wyżej, dzięki czemu nie ulegną one przypadkowej eliminacji. Ocenę wykonywali architekci krajobrazu, którzy zdawali sobie sprawę z kierunku proponowanych w projekcie zmian i mieli świadomość, że w miejscach, gdzie będzie się koncentrował ruch wypoczynkowy wartość biocenotyczna drzew i innych elementów przyrodniczych będzie ulegała obniżeniu. Drzewa o niespotykanej w innych obiektach wartości powinny być zachowane, a ruch turystyczny powinien być ograniczony. Oceniając pojedyncze drzewa podnoszono lub obniżano ich wartość w zależności od położenia w parku. Drzewa położone w strefie brzegowej drzewostanu - w granicy zewnętrznej (ryc. 2) lub w okrajkach między różnymi zbiorowiskami (ryc. 3) otrzymywały dodatkowe punkty. Najwyżej oceniano drzewa o wyjatkowych wartościach, jak np. drzewa z dużymi gniazdami ptaków szponiastych (ryc. 4). Niektórym drzewom obniżano wartość biocenotyczną z uwagi na położenie w strefie intensywnego wykorzystania, np. w centralnej części parku przy budynku lub alei wjazdowej (ryc. 5). Analizując położenie drzew w strukturze parku i inne walory krajobrazu wydzielono obszary pod względem różnej wartości. 

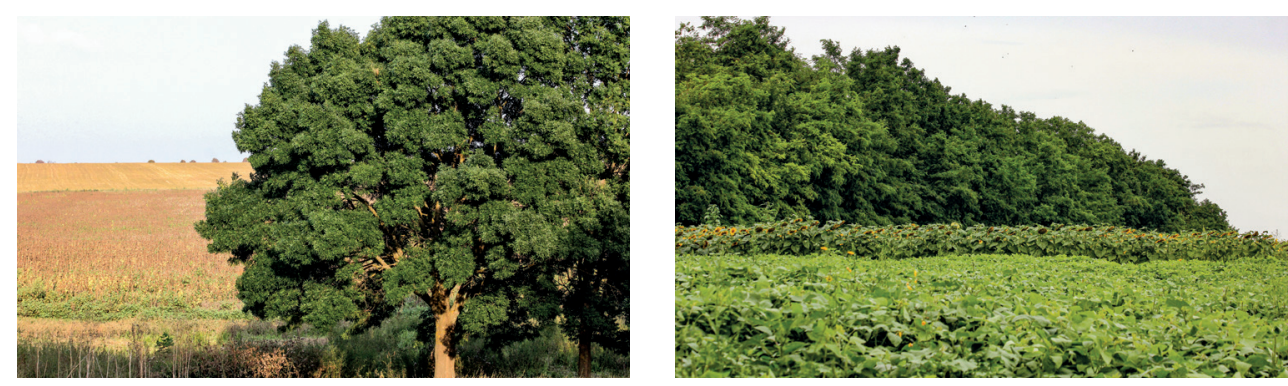

Ryc. 2. Drzewa o podwyższonej wartości biocenotycznej położone w zewnętrznej okrajce parku
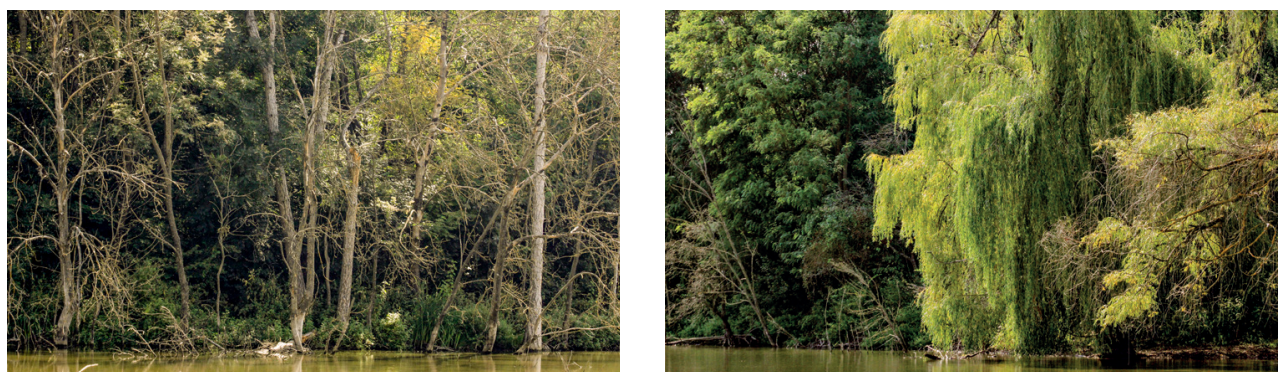

Ryc. 3. Drzewa o podwyższonej wartości biocenotycznej położone w wewnętrznej okrajce parku
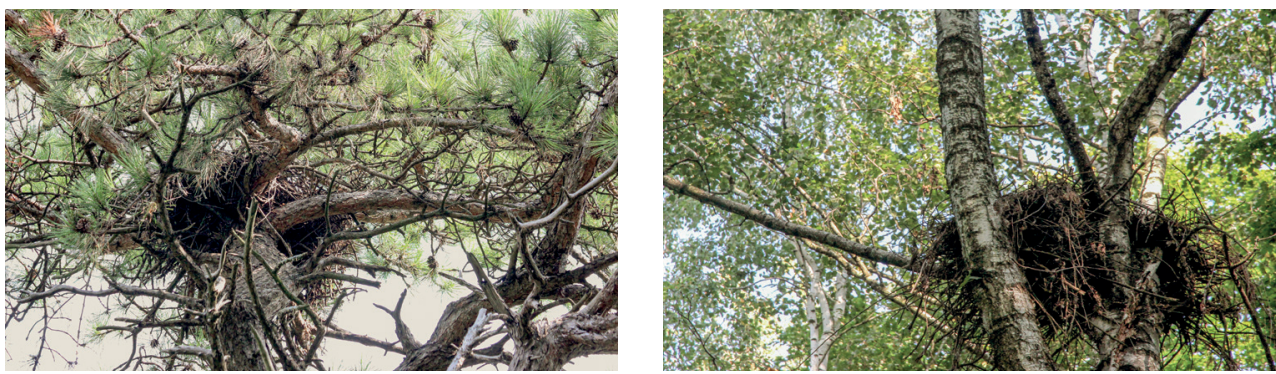

Ryc. 4. Drzewa w parku o najwyższej nabytej wartości biocenotycznej. Stare gniazdo zajmowane przemiennie przez ptaki szponiaste lub kruki
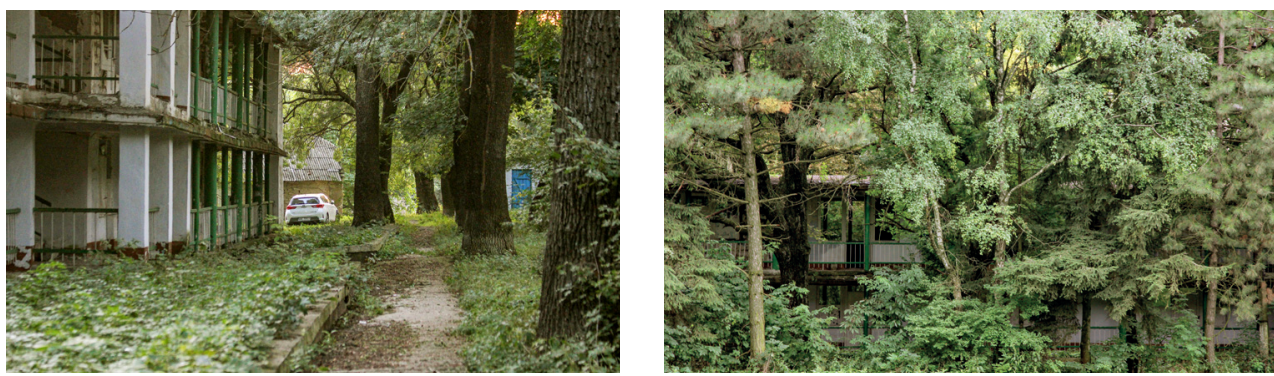

Ryc. 5. Drzewa o obniżonej wartości biocenotycznej z uwagi na położenie w strefie intensywnego wykorzystania w centralnej części parku 
W Parku „Willa Mindic” nie trzeba przywracać wartości biocenotycznej terenowi zdegradowanemu, co jest głównym celem wszelkich proekologicznych działań szeroko opisywanych w ostatnich latach, gdy te wartości są nie tylko identyfikowane, ale także eksponowane. Coraz bardziej rozpowszechnia się trend rewitalizacji, czy renaturalizacji ${ }^{4}$. Także w nowo projektowanych parkach wydziela się enklawy cenne dla flory i fauny, ale bardzo rzadko mamy do czynienia z unikatowymi w skali kraju, a nawet Europy wartościami, jak niewątpliwie można określić nietypowe dla współczesnych czasów zasoby przyrodnicze parku „Willa Mindic". Park ten ma wysokie walory biocenotyczne głównie z powodu otaczających go rozległych pól uprawnych pozbawionych dużych, starych drzew (ryc. 6). W czasie waloryzacji dokonywano też oceny drzew pod względem stanu zdrowotnego oraz ochrony przyrody [Ozimkowska, Wojtatowicz, Jancelewicz 2014]. Ocenę prowadził trzyosobowy zespół, w którym jedna z osób specjalizowała się w ocenie stanu zdrowotnego, druga oceniała drzewo pod względem wartości biocenotycznej i ochrony przyrody. Drzewo oceniano uwzględniając jego osobnicze cechy biologiczne i nabyte, powiązania z najbliższym otoczeniem oraz położenie

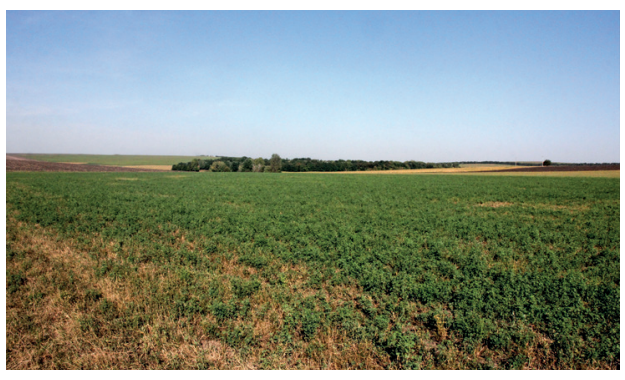

Ryc. 6. Położenie Parku „Villa Mindic” w krajobrazie rolniczym $\mathrm{w}$ parku i umiejscowienie w odniesieniu do ekosystemów poza parkiem. Trzecia osoba koordynowała i kontrolowała wyniki, co miało znaczenie wobec dużej liczby ocenianych drzew jednocześnie pod trzema względami. Waloryzacja opierała się na celu badawczym, którym w tym przypadku było określenie przydatności analizowanych drzew dla flory i fauny danego stanowiska w określonym czasie, ale jej wyniki mają odniesienie do innych aspektów, jak projektowany sposób zagospodarowania terenu. Określona na etapie inwentaryzacji wartość biocenotyczna może ulec przekształceniu po wprowadzeniu zmian w otoczeniu badanego drzewa. Niejednokrotnie zabiegi rewaloryzacji, modernizacji, a nawet pielęgnacji zamiast zachowywać i przywracać to obniżaja wartość przyrodniczą obiektu lub jego fragmentów. Liczne badania porównawcze zasobów przyrodniczych parków przed i po ich renowacji wykazują ich zubożenie [Luniak, Węgrzynowicz 2019; Popko 2008]. W celu uniknięcia niebezpieczeństwa przekształcenia cennego przyrodniczo terenu w typowy obiekt architektury krajobrazu, gdzie główna funkcja jest wypoczynek ludzi, a inne funkcje zdefiniowane sa jako towarzyszące, posłużono się wynikami oceny zarówno wartości biocenotycznej drzew, jak i ich stanu zdrowotnego. Wykonywane osobno oceny dopiero po zestawieniu w jednej tabeli z odniesieniem do usytuowania na podkładzie geodezyjnym i zamysłu projektowego, pozwoliły na ostateczna ocenę; np. drzewo spróchniałe o dużej wartości biocenotycznej było zakwalifikowane do pozostawie-

\footnotetext{
${ }^{4}$ patrz: Park na wyspach w Holandii 2001-2008, Parc de Saint Jacques de la Lande, Ille-Vilaine, Francja 2007-2013, który w 2012 r. otrzymał główną nagrodę za tereny podmokłe na obszarach zurbanizowanych) [http:/ / www.brueldelmar.fr/ fr/ project/22/ parc-ecologique-de-saint-jacques].
} 
nia, gdy znajdowało się na terenie, który w projekcie nie musiał być udostępniony dla ludzi, natomiast, gdy rosło w miejscu dużej penetracji, musiało w końcowej ocenie zostać przeznaczone do wycięcia.

\section{Metoda oceny drzew w Parku „Willa Mindic”}

Inwentaryzacja drzewostanu została wykonana w terminie od 21 do 30 lipca oraz od 1 do 9 września 2014 r. Prace kameralne zakończono 10 października 2014 r. Wyniki badań przedstawiono $\mathrm{w}$ postaci graficznej i opisowej (w tabeli). W przypadku braku możliwości wykonania pomiaru w tabeli podano jedynie nazwę drzewa. Pomiary dendrometryczne wykonywane w zakresie inwentaryzacji podstawowej, która dotyczy określenia rodzaju i gatunku drzewa, jego wysokości, obwodu pnia oraz zasięgu korony rozszerzono o opis stanu zdrowotnego drzewa i jego wartości biocenotycznej. Poszczególne dane określane zostały następująco:

- Wysokość drzewa za pomocą wysokościomierza Nikon Laser Forestry Pro

- $\quad$ Obwód pnia za pomocą taśmy mierniczej na wysokości $=130 \mathrm{~cm}$

- Zasięg korony za pomocą taśmy mierniczej.

- Stan zdrowotny drzewa określono przyjmując czterostopniową skalę i oznaczono literami $\mathrm{A}-\mathrm{D}$, gdzie:

A - w pełni wykształcona forma drzewa (pień, korona), charakterystyczna dla gatunku. Faza witalności (wg Roloffa) - FW0, FW1. Brak widocznych oznak chorób oraz patogenów. Posusz do 5\%.

B - drzewo z widocznymi defektami w obrębie pnia i korony z możliwością ich odbudowy. Faza witalności FW1, FW2. Posusz do 25\%.

$\mathrm{C}$ - widoczne drobne ubytki powierzchniowe na pniu. Korona zredukowana lub silnie przerzedzona, wciąż z możliwością częściowej odbudowy. Posusz do 50\%.

D - widoczne ślady chorób i patogenów (pierwotnych i wtórnych). Duże ubytki wgłębne pnia. Korona silnie zredukowana bez możliwości regeneracji. Faza witalność FW3. Posusz powyżej 50\%. Drzewo zamierające lub obumarłe.

Skala Roloffa:

FW0 - faza eksploracji - intensywnego rozwoju

FW1 - faza degeneracji - osłabionego rozwoju

FW2 - faza stagnacji - brak rozwoju

FW3 - faza rezygnacji - zamieranie

- Wartość biocenotyczną oraz znaczenie dla ochrony przyrody określono przyjmujacc pięciostopniową skalę i oznaczono cyframi rzymskimi I-V, gdzie:

I - drzewo rośnie w bezpośredniej bliskości siedzib ludzkich, ruchliwych dróg komunikacji pieszej oraz w miejscach intensywnie penetrowanych przez ludzi. Rośnie w głębi drzewostanu i jest jednym z egzemplarzy dużej grupy monokulturowej. Nie wyróżnia się z otoczenia rozmiarami i budowa. Korona przerzedzona. Brak dziupli i innych miejsc 
sprzyjających schronieniu, wypoczynkowi, lęgom i rozrodowi zwierząt o znacznych wymiarach. Gatunek, szczególnie, gdy jest obcego pochodzenia (np. klon jesionolistny), zaliczany do grupy ekspansywnych, ograniczający rozwój miejscowej fauny i flory. Niska wartość pod względem pożytków, a zwłaszcza pokarmu dla wielu gatunków zwierząt. II - drzewo rosnące w niewielkiej odległości od siedlisk ludzkich, dróg komunikacji pieszej oraz miejsc penetrowanych przez ludzi. Rośnie w głębi drzewostanu i jest jednym z egzemplarzy grupy monokulturowej. Nie wyróżnia się z otoczenia rozmiarami i budową. Korona przerzedzona. Brak dziupli i innych miejsc sprzyjających schronieniu, wypoczynkowi, lęgom i rozrodowi zwierząt o znacznych wymiarach. Gatunek, szczególnie, gdy jest obcego pochodzenia, ograniczający rozwój miejscowej fauny i flory. Niska wartość pod względem pożytków, a zwłaszcza pokarmu dla zwierząt.

III - drzewo rośnie na uboczu siedzib ludzkich, dróg komunikacji pieszej oraz w miejscach rzadko penetrowanych przez ludzi w okresie lęgu i rozrodu. Rośnie w głębi drzewostanu lub małej grupy monokulturowej. Nie wyróżnia się z otoczenia rozmiarami i budowa. Ograniczona liczba miejsc sprzyjających schronieniu, wypoczynkowi, lęgom i rozrodowi zwierzat o znacznych wymiarach. Gatunek niewpływajacy w widocznym stopniu na rozwój miejscowej fauny i flory. Przeciętna wartość pod względem pożytków, a zwłaszcza pokarmu dla rodzimych gatunków zwierząt.

IV - drzewo rośnie poza strefą intensywnej penetracji w okresie lęgu i rozrodu zwierząt oraz bujnego rozwoju runa i podszycia. Wyróżnia się z otoczenia rozmiarami i budową. Posiada dużą liczbę potencjalnych miejsc sprzyjających schronieniu, wypoczynkowi, leggom i rozrodowi zwierzat o znacznych wymiarach. Gatunek rodzimy lub nie ekspansywny obcego pochodzenia, umożliwiający rozwój rodzimej fauny i flory. Znacząca wartość pod względem pożytków, a zwłaszcza pokarmu dla wielu gatunków zwierząt. $\mathrm{V}$ - drzewo rośnie w strefie całorocznej ekstensywnej penetracji przez ludzi, jako samotnik lub na skraju drzewostanu. Jest naturalnym cennym składnikiem rodzimego zbiorowiska roślinnego. Wyróżnia się z otoczenia rozmiarami i budową. Korona i pień z dziuplami sprzyjaja budowie gniazd i innych miejsc rozrodu oraz schronieniu i wypoczynkowi zwierząt o znacznych wymiarach. Bardzo wysoka wartość pod względem pożytków, a zwłaszcza pokarmu dla rodzimych gatunków zwierząt. Gatunek zaliczany do rodzimej, rzadkiej lub chronionej flory.

\section{Ogólne wyniki oceny stanu zdrowotnego i wartości biocenotycznej drzew na terenie parku „Willa Mindic" w Mołdawii}

Badania rozszerzonej inwentaryzacji dendrologicznej i waloryzacji, której wyniki zebrano w tabeli (ryc. 7)5, przeprowadzono na 1400 osobnikach. Największą wartość biocenotyczną (V) odnotowano dla 181 drzew, co stanowi 13 \% zasobów. Wśród nich najliczniejsza

\footnotetext{
${ }^{5}$ Autorem wszystkich ilustracji zamieszczonych w artykule (ryc. 7-10) jest Tomasz Wojtatowicz.
} 
grupę stanowia jesiony, klony, wierzby i graby. Porównując drzewa o najwyższej wartości biocenotycznej z ich stanem zdrowotnym zanotowano jedynie trzy sztuki zakwalifikowane do najwyższej kategorii stanu zdrowotnego oznaczonej litera A, 56 sztuk zakwalifikowano do kategorii B, jako drzewa z widocznymi defektami w obrębie pnia i korony z możliwością ich odbudowy. 70 szt. to kategoria C, czyli drzewa o widocznych drobnych ubytkach powierzchniowych na pniu. Korona zredukowana lub silnie przerzedzona, posiadają możliwość częściowej odbudowy. 53 szt. jako drzewa zamierające lub obumarłe zakwalifikowano do kategorii D bez możliwości regeneracji.

\begin{tabular}{|c|c|c|c|c|c|c|c|}
\hline \multirow{3}{*}{$\begin{array}{c}\begin{array}{c}\text { numer } \\
\text { na } \\
\text { mapie }\end{array} \\
1 \\
\end{array}$} & ENA STANU ZL & $\begin{array}{l}\text { WOTNEGO I WA } \\
\text { PARKU VILL }\end{array}$ & $\begin{array}{l}\text { OŚCI BI } \\
\text { MINDIC V }\end{array}$ & $\begin{array}{l}\text { VENOT } \\
\text { MOLDA }\end{array}$ & :ZNEJ D & RZEW NA & A TERENIE \\
\hline & \multicolumn{2}{|c|}{ gatunek } & \multirow{2}{*}{$\begin{array}{c}\text { obwód [cm] } \\
185\end{array}$} & \multirow{2}{*}{$\begin{array}{c}\begin{array}{c}\text { rzut } \\
\text { średnicy } \\
\text { korony }\end{array} \\
9 \\
\end{array}$} & \multirow{2}{*}{$\begin{array}{c}\text { wysokość } \\
8,0 \\
\end{array}$} & \multirow{2}{*}{\begin{tabular}{|c} 
stan \\
zdrowotny
\end{tabular}} & \multirow{2}{*}{\begin{tabular}{|c}
$\begin{array}{c}\text { wartość } \\
\text { biocenotyczna }\end{array}$ \\
III \\
\end{tabular}} \\
\hline & klon pospolity & Acer platanoides & & & & & \\
\hline 2 & jesion wyniosły & Fraxinus excelsior & $40+108$ & 10 & 8,0 & C & III \\
\hline 3 & jesion wyniosły & Fraxinus excelsior & 60 & 9 & 8,0 & C & I \\
\hline 4 & jesion pensylwański & Fraxinus pennsylvanica & $87+87$ & 7 & 7,5 & C & II \\
\hline 5 & wierzba krucha & Salix fragilis & $226+217$ & 17 & 10,5 & C & IV \\
\hline 6 & klon polny & Acer campestre & 23 & 11 & 9,0 & C & IV \\
\hline 7 & grusza pospolita & Pyrus pyraster & 70 & 5 & 9,0 & B & IV \\
\hline 8 & klon pospolity & Acer platanoides & 113 & 12 & 11,0 & B & III \\
\hline 9 & czereśnia ptasia & Prunus avium & 90 & 6 & 12,0 & A & IV \\
\hline 10 & klon pospolity & Acer platanoides & 88 & 7 & 12,0 & $\mathrm{~B}$ & II \\
\hline 11 & czereśnia ptasia & Prunus avium & $95+70$ & 8 & 9,0 & C & IV \\
\hline 12 & jabłoń domowa & Malus domestica & 70 & 5 & 4,0 & C & II \\
\hline 13 & śliwa ałycza & Prunus cerasifera & $28-86$ & 9 & 6,5 & C & III \\
\hline
\end{tabular}

Ryc. 7. Przykładowa karta ewidencyjna z oceną stanu zdrowotnego i wartości biocenotycznej drzew

Powstały problem badawczy nie wynikał ze sposobu wykonywania oceny, a z jej właściwej interpretacji. Wykorzystana metoda nie jest problematyczna, gdy wykonuje ja osoba nie analizująca wyników. Traktowana jako rozszerzone badanie inwentaryzacji drzew jest właściwym narzędziem prowadzącym do jasno sprecyzowanych wniosków zakładając, że nie przewiduje się zmiany sposobu użytkowania terenu, a jedynie jego monitorowanie. W momencie, gdy dochodzi do interpretacji wyników, same dane opisowe, a tym bardzie liczbowe nie moga zostać automatycznie przełożone na decyzje projektowe w zakresie zmiany zagospodarowania terenu.

\section{Wykorzystanie analiz przedprojektowych do sprecyzowania wytycznych projektowych}

Metoda oceny wartości biocenotycznej okazała się wysoce przydatna przy opracowaniu koncepcji zagospodarowania terenu w „Willa Mindic”. Należy stwierdzić, że nie zawsze konieczna jest ocena wartości biocenotycznej drzew. Gdy funkcja wiodąca jest ochrona przy- 
rody, np. w rezerwatach przyrody czy parkach narodowych, zazwyczaj położenie drzewa nie ma istotnego wpływu na ocenę jego wartości, bowiem jest ono z założenia chronione i nie wymaga waloryzacji. Podobnie przedstawia się sytuacja gdy projektant nie uwzględnia wartości biocenotycznej drzew, a kieruje się jedynie potrzebami inwestora, możliwościami finansowymi i współczesnymi trendami w projektowaniu (estetycznymi, kompozycyjnymi, funkcjonalnymi, materiałowymi itp.). Bywa też, że projektant ma ogólne rozeznanie co do osobniczej, biocenotycznej wartości drzewa lecz jego celem nie jest analiza następstwa, jakie spowoduje realizacja projektu. W tych przypadkach problem ochrony przyrody jest marginalizowany, a problem etyczny obniżenia lub niszczenia wartości niezauważany. Wartości biocenotyczne po realizacji projektu będą dziełem przypadku. Znając rozmieszczenie istotnych miejsc i wartości biocenotycznych możliwe jest już na etapie oceny szacowanie zysków i strat spowodowanych realizacja głównego celu. W takim przypadku istnieje większa szansa ochrony wartości przyrodniczych, gdyż wartość każdego drzewa oceniana jest kompleksowo, np. uwzględnia bezpieczeństwo ludzi. W ten sposób uzyskuje się informacje nie tylko o wartości drzewa z punktu widzenia wypoczynkowego, lecz także strat spowodowanych obniżeniem wartości przyrodniczej całego obiektu. Tym samym narzędziami projektowymi można do pewnego stopnia rekompensować uszczerbki powstałe w miejscach o intensywnym wykorzystaniu rekreacyjnym. Inwentaryzacja drzew skorelowana z oceną ich wartości zdrowotnej oraz biocenotycznej, a także występowaniem szczególnych elementów przyrodniczych i historycznych, posłużyła do wykonania planu przedstawiającego uproszczony układ graficzny terenów z podziałem na trzy kategorie (ryc. 8). Schemat przedstawia ogólne wytyczne do projektu rewaloryzacji z uwzględnieniem zarówno skutków głębokich przeobrażeń, sfery niematerialnej jak i materialnej. Wśród nich można odnotować zmiany użytkowania terenu, rodzaju przestrzeni, funkcji podstawowych obiektu, przyrody i kultury, a także ekspozycji. Do nowego projektu powinny być wykorzystane wszystkie pierwotne elementy materialne, np. wyjścia z willi i okazałe drzewa (dwa świerki pospolite i sosny czarne) oraz niematerialne - odnoszące się do funkcji reprezentacyjnej i wypoczynkowej w duchu epoki z czasów Ohanowiczów, także elementy nabyte odnoszące się do funkcji zarządzania całym obiektem. Czerwonym kolorem wyróżniono obszary, których zagospodarowanie musi zapewniać pełne bezpieczeństwo ludzi w strefie dojść i dojazdów. Znajduja się przy bramach wjazdowych, wejściach do stale użytkowanych budynków, wzdłuż ciagów komunikacyjnych oraz innych miejscach, które będą wykorzystywane przez ludzi. Druga kategorię stanowią tereny o dużym znaczeniu dla życia i rozwoju flory i fauny. Czarne pola oznaczają tereny, na których zwiedzanie i wypoczynek będą ograniczone. Na żółto zaznaczono obszary, gdzie ze względu na wyjątkowe wartości biocenotyczne nie przewiduje się ciagów komunikacyjnych i miejsc stałego wypoczynku.

Ten uproszczony plan posłużył do podjęcia dalszych decyzji projektowych. Dla osiagnięcia celu przeprowadzono standardowy tok postępowania przyjęty w projektowaniu obiektów architektury krajobrazu. W ramach działań przedprojektowych wykonano szereg analiz dotyczących układu przyrodniczego, funkcjonalnego, kompozycyjnego i historycznego. 


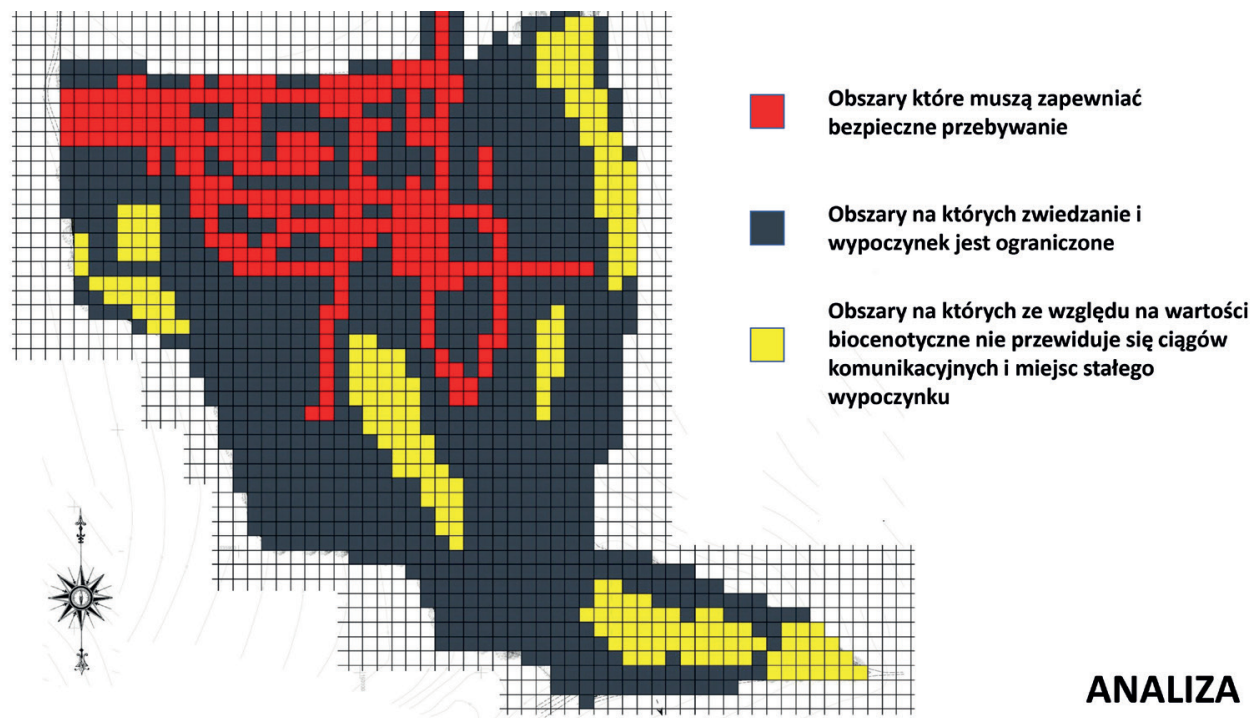

Ryc. 8. Schemat rozmieszczenia obszarów o różnej intensywności wykorzystania wypoczynkowego z uwzględnieniem wartości biocenotycznych

Identyfikacja niepodważalnych wartości przekłada się zarówno na szanse, jak i zagrożenia dla terenu. Szansą jest niewatpliwie możliwość podkreślenia niezwykłości miejsca, zagrożeniem zaś, konieczność utrzymania i wkomponowania pewnych żywych lub nieożywionych elementów, które nie zawsze mają uzasadnienie swej egzystencji we współczesnym parku. Nieumiejętna adaptacja może powodować niewygodę dla użytkownika, a nawet być odbierana jako karykaturalna. Może też w znaczny sposób zubożyć przyrodę. Dzieje się tak w przypadku przekształcania szaty roślinnej, wycinki dziuplastych drzew, przerzedzania zwartych krzewów, zastępowania rodzimej flory roślinami egzotycznymi o niewielkiej wartości dla ekosystemu, a nawierzchni przepuszczalnych wygodniejszymi utwardzonymi. Aby uniknąć wyżej wymienionych zagrożeń w projekcie koncepcyjnym parku „Willa Mindic” poszerzone badania przyrodnicze uzupełniono kwerendą biblioteczną.

Wykazano, że obiekt był przez wiele lat wykorzystywany niezgodnie z pierwotną funkcja, stąd zniszczeniu uległo wiele elementów istniejących w czasie tworzenia ogrodu przez właścicieli zarządzających nim przed II wojną światową [Ozimkowska, Wojtatowicz 2016]. Brak planów i innych dokumentów oraz źródeł ikonograficznych upoważnia do stwierdzenia, że zniszczenia te maja charakter trwały - powstały nieodwracalne zmiany. Dodatkowo zmiany te zostały spotęgowane w okresach, kiedy zarówno park, jak i obiekty budowlane nie podlegały zabiegom pielegnacji i konserwacji. Wychodząc z założenia, że przy wypoczynkowym wykorzystaniu parku wartości przyrodnicze zasługują na szczególną ochronę wyodrębniono obszary o wyjątkowym znaczeniu dla roślin i zwierząt (ryc. 9). 


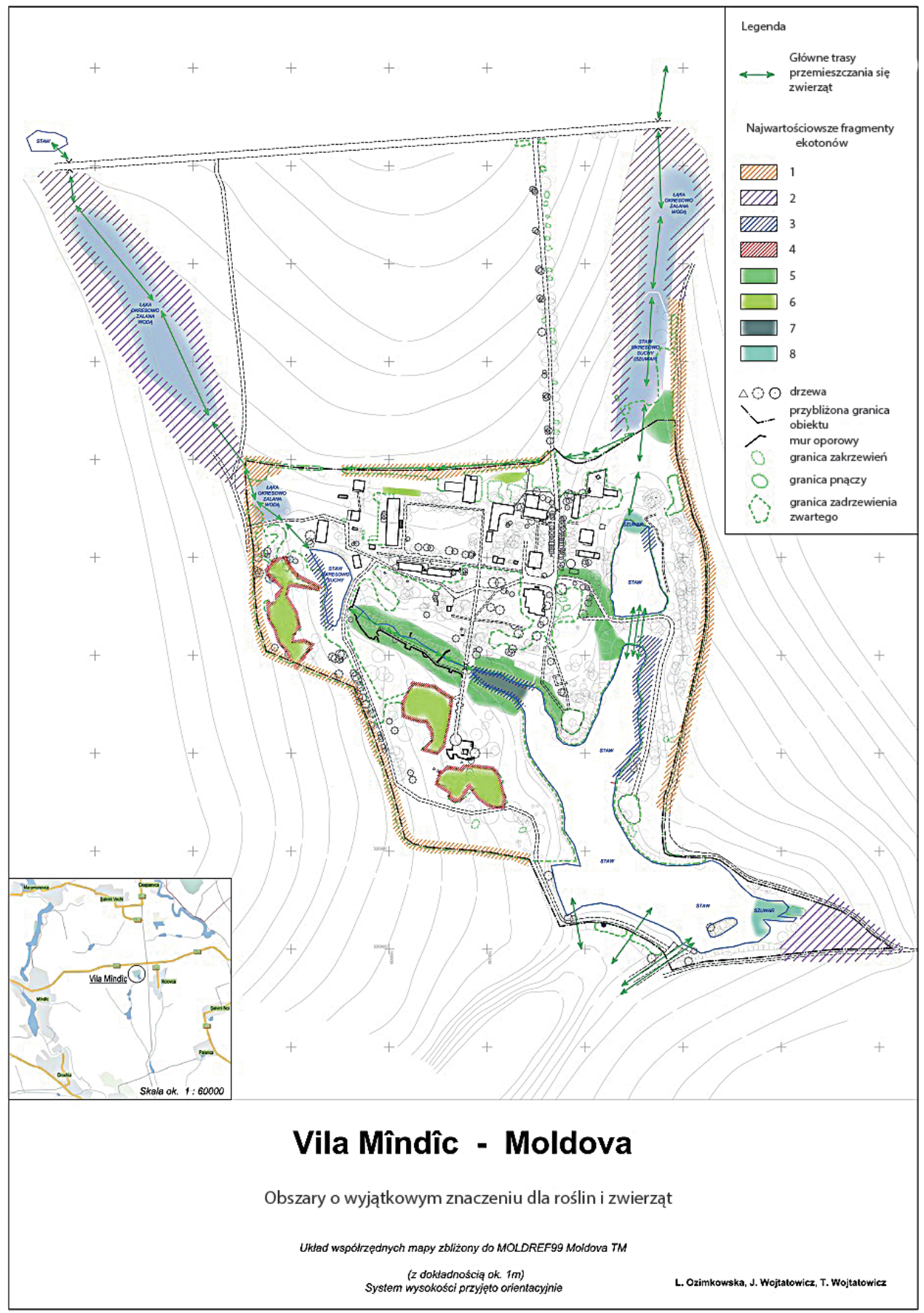

Ryc. 9. Obszary o wyjątkowym znaczeniu dla roślin i zwierząt 
- Ekoton między drzewostanem parkowym a gruntami ornymi (1)

- Ekoton między łąkami a gruntami ornymi (2)

- Ekoton między drzewostanem parkowym a wodą (3)

- Okrajkę między drzewostanem parkowym a łąkami parkowymi (4)

- Drzewa i ich skupiny (5)

- $\quad$ Łąki i murawy o dużym znaczeniu dla zwierząt (6)

- Tereny zabagnione (7)

- $\quad$ Szuwary (8)

Zaznaczone tereny, szczególnie, jeśli występowały na nich drzewa o wyjątkowych walorach biocenotycznych starano się ochronić przed przyszłą ekspansją form wypoczynkowych. Było to dużym problemem nie w momencie kwalifikacji drzewa, które miało wysokie walory, a w trakcie podejmowania decyzji projektowych. Gdy drzewo rosło w grupie o zbliżonych wartościach starano się zachować całą grupę, natomiast dylematy pojawiały się, gdy wartościowe biocenotycznie drzewo występowało jako soliter na obszarze o przeciętnych wartościach z punktu widzenia przyrodniczego i rekreacyjnego. W tym wypadku decyzja wyodrębnienia drzewa z jego otoczeniem jako terenu pozostawionego przyrodzie była w sprzeczności z wytycznymi zagospodarowania wypoczynkowego. Dylematów takich nie ma projektant typowego obiektu architektury krajobrazu, w którym głównym celem jest przystosowanie całego terenu do funkcji wypoczynkowej. Przydatną w tym przypadku stała się analiza pozostałych składników i niektórych cech krajobrazu, po wykonaniu których można było skonkretyzować decyzje projektowe. $\mathrm{W}$ rezultacie projekt koncepcyjny zagospodarowania terenu uwzględnia wiele form rekreacji i wypoczynku z dala od najcenniejszych terenów. Na obszarach o ograniczonej penetracji ludzi można będzie obserwować, jak zachowanie i wzbogacenie florystyczne fragmentów parku wpływa nie tylko na zwierzęta i grzyby, ale i na zachodzące związki między różnymi organizmami tu występującymi ${ }^{6}$ [Wojtatowicz 1994].

\section{Opis idei projektowej zagospodarowania parku „Wila Mindic"}

Badania wykazały, że w wyniku procesu sukcesji w parku zaistniało wiele wartości przyrodniczych, które w procesie rewaloryzacji obiektu powinny być zachowane w jak największym stopniu i wykorzystane tak z punktu widzenia potrzeb wypoczynkowych, jak ochrony zasobów przyrodniczo-kulturowych. Z tego powodu w koncepcji przewidziano opracowanie szczegółowych projektów dla obszarów o kluczowym znaczeniu w celu zachowania wartości przyrodniczej całego założenia. Szczegółowe wykonanie indywidualnych rozwiązań powinno uwzględniać wszystkie ważne dla zachowania swoistych wartości parku biotopy, zbiorowiska roślinne i zwierzęce. Rozwiązania te obejmą najcenniejsze fragmenty drzewostanu, szuwaru, łąk kwietnych, a także korytarzy migracji zwierząt i terenów głów-

\footnotetext{
${ }^{6}$ np. dziupla, powstała w wyniku wyłamania konaru i destrukcyjnej działalności grzyba czy wykuta przez kowalika, zajmowana będzie przez innego ptaka lub owady.
} 
nego nurtu spływu powierzchniowego wody po wiosennych roztopach i dużych opadach. Wykonanie projektów musi być spójne z całą koncepcją rewaloryzacji założenia, a przede wszystkim zachowaniem priorytetu funkcji podstawowej jaka jest funkcja wypoczynkowa w obiekcie historycznym. Istotnym elementem koncepcji sa punkty widokowe i obserwacyjne obiektów i elementów historycznych, przyrodniczych i krajobrazowych. W miarę możliwości starano się zlokalizować je w dawnych miejscach widokowych. Zaprojektowano też szereg nowych punktów widokowych, w których powstały nowe wartościowe elementy godne obserwacji, w tym także wywrócone czy zamierające drzewa o dużej wartości biocenotycznej, które w wielu przypadkach są malownicze. Projekt koncepcyjny rewaloryzacji terenu obejmuje ogród romantyczny oraz park spacerowy. Głównym elementem kompozycji przestrzennej XIX-wiecznego założenia parkowego był cypel od północy wchodzacy w głąb jeziora, z którego rozchodziły się w różnych kierunkach osie widokowe. W kierunku południowym wzdłuż jeziora, w kierunku północno-wschodnim w lewą odnogę jeziora oraz w kierunku północno-zachodnim w prawą odnogę jeziora, a także w kierunku Elizeum, tj. Kaplicy Ohanowiczów. Wyróżniającym elementem układu przestrzennego jest aleja grabowa prowadząca do kaplicy, zakończona okazałymi orzechami czarnymi.

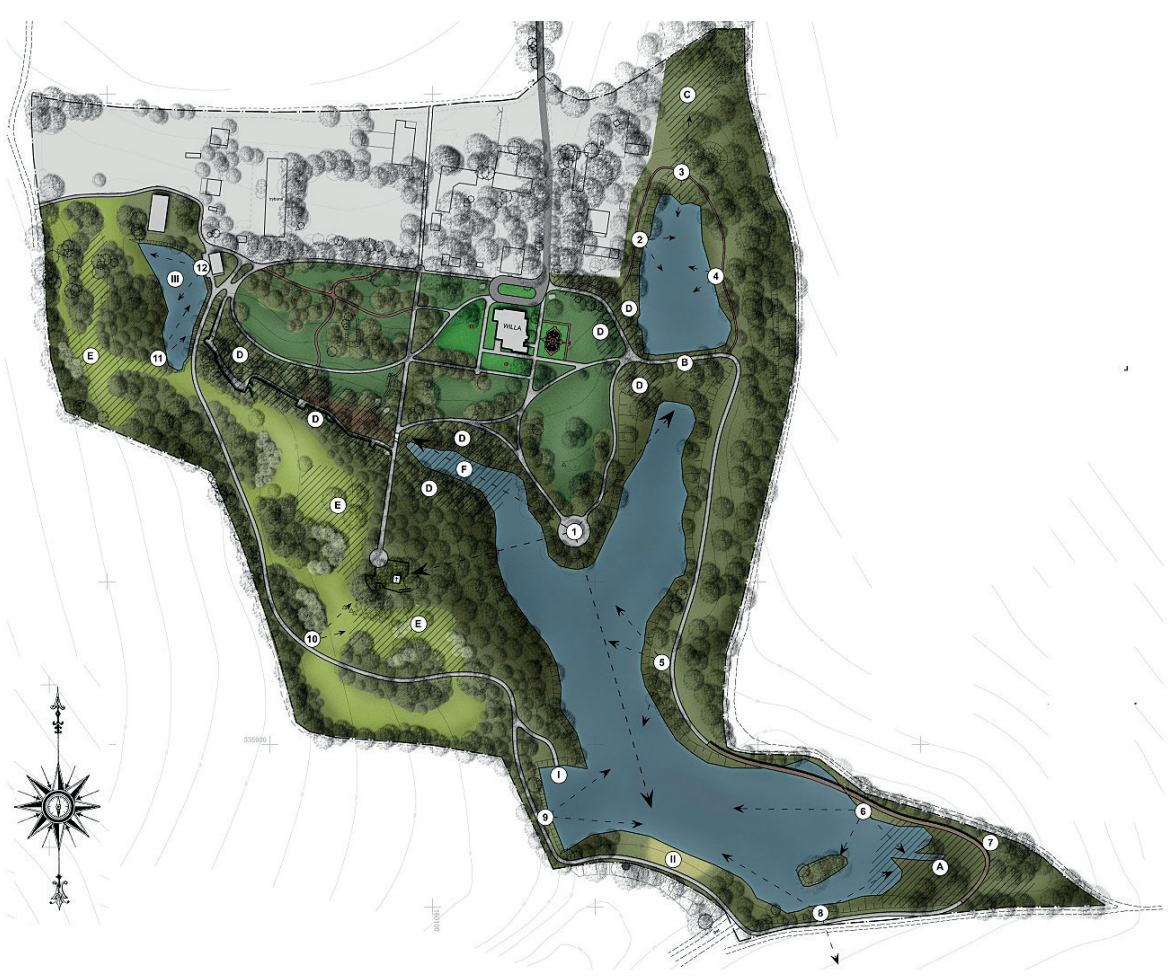

Ryc. 10. Projekt koncepcyjny zagospodarowania terenu 
Na projekcie koncepcyjnym (ryc. 10) cyframi rzymskimi oznaczono:

I. Zatoka z pomostami do cumowania łódek

II. Plaża trawiasta

III. Staw przeznaczony do bagrowania

Cyframi arabskimi wyróżniono:

1. Obserwatorium z altaną, główny punkt widokowy założenia

2. Obserwacja ze skarpy jeziora i wschodniego drzewostanu przy stawie

3. Przejście przez ciek $\mathrm{z}$ widokiem na staw i groblę oraz $\mathrm{w}$ kierunku stoku

4. Widok przy lustrze wody na zachodnią skarpę stawu

5. Polana biesiadna $\mathrm{z}$ widokiem na jezioro i drzewostanem na skarpach

6. Czatownia z widokiem na wyspę i miejsca przebywania zwierząt

7. Miejsce do wypoczynku z możliwością obserwacji pól i szuwarów

8. Widoki ze skarpy na jezioro i obszary rolnicze

9. Widoki na wschodni brzeg jeziora oraz przystań

10. Widoki na polany z drzewami owocowymi, okazałymi orzechami czarnymi oraz kaplice

11. Widok na zabytkowy dom i taras nad stawem

12. Widok $\mathrm{z}$ tarasu na drzewostan po zachodniej stronie stawu.

Literami zaznaczono miejsca wymagające projektów szczegółowych ze względu na uwarunkowania przyrodnicze:

A. Miejsca lęgowe ptaków i główne miejsce życia żółwi błotnych proponowane do objęcia ochrona, z zakazem wstępu

B. Trasa wędrówek zwierząt

C. Miejsce spływu wody i migracji zwierzat

D. Drzewostany o wyjatkowych walorach biocenotycznych

E. Łaki kwietne o wyjątkowych walorach przyrodniczych

F. Tereny zabagnione o wyjątkowych walorach przyrodniczych

Ze względów niezależnych od zespołu, prace nie zostały kontynuowane w następnych latach, w związku z czym nie powstały projekty wykonawcze.

\section{Ogólne podsumowanie i wnioski}

Zastosowanie metody oceny biocenotycznej drzew, która została wykorzystana w pracach przedprojektowych w parku „Willa Mindic” miało duży wpływ na wnioski do projektu koncepcyjnego zagospodarowania terenu. Rozszerzenie inwentaryzacji o waloryzację drzew z punktu widzenia ich przydatności biocenotycznej z jednej strony pozwoliło zidentyfikować miejsca najbardziej wartościowe przyrodniczo, z drugiej ukazało konflikty występujące między naturą a kulturą. Dzięki szczegółowej identyfikacji wartości biocenotycznej drzew i ich porównaniu z ocena zdrowia oraz znaczeniem dla ochrony przyrody, architekt krajobrazu posługujacy się tak pogłębionymi w stosunku do zwyczajowych praktyk badaniami, ma możliwość wykonania projektu, który zaspokaja potrzeby wypoczynkowe różnych grup 
użytkowników i zachowuje wyjątkowe wartości przyrodnicze, które często nie są kompleksowo identyfikowane we współczesnych obiektach. W efekcie część najatrakcyjniejszych terenów została pozostawiona przyrodzie, a na innych obszarach po realizacji projektu, np. w bezpośrednim sassiedztwie willi z pewnością zubożeje flora i fauna.

Badania przy użyciu metody biocenotycznej oceny drzew pokazują, że występują zależności między ocena stanu zdrowotnego i oceną wartości biocenotycznej. Związki i zależności występujące między tymi ocenami wydają się na tyle interesujące, że mogą być przedmiotem szczegółowych badań naukowych w zakresie korelacji między wynikami z zastosowaniem metod statystycznych. Stwierdzono, że wraz ze wzrostem wartości biocenotycznej drzewa (np. dziuplastego, wypróchniałego) wzrasta zagrożenie bezpieczeństwa dla ludzi. W innym przypadku drzewa słabe, zamierające mają niższą wartość od drzew silnych, zdrowych, obficie kwitnących, owocujących dobrze maskujących gniazda. Wraz z wiekiem drzew, wzrostem ich rozmiarów stwierdza się, że w ogólnym ujęciu wzrasta ich wartość biocenotyczna, dendrologiczna, ekologiczna, ochrony przyrody, historyczna a nawet wypoczynkowa, w tym estetyczna. Na etapie badań przedprojektowych spostrzeżono wiele innych powiązań, lecz nie obejmował ich zakres rozważań. Bez poszerzonych badań przyrodniczych projektant nie jest w stanie przewidzieć negatywnych skutków swoich działań. Wydaje się, że zastosowanie metody biocenotycznej oceny drzew, mimo że jest czasochłonna i wymaga podejmowania decyzji projektowych na etapie analiz, prowadzi do optymalnego wykorzystania terenu. Biorac pod uwagę założenia metodologiczne waloryzacja drzew w parku „Willa Mindic” w pełni sprostała wymogom rozszerzonej analizy dendrologicznej, choć ukazała złożoność problemów związanych z jej wynikami. Przeprowadzone badania stanowią rodzaj studium przypadku. Podobna analiza zakończona projektem mogłaby być przedmiotem kolejnych badań.

\section{Literatura}

Dormidontovna. V.V., 1992, Historyczna charakterystyka i stan wspótczesny starych parków Motdawii, Garmoiâ iskustva i prirody, Kišinev.

Dujanowicz K., Werner B., 2013, Analiza możliwości adaptacji obiektu polskiego dziedzictwa narodowego: założenia architektoniczno-parkowego "Willa Mindic" na międzynarodowe centrum pogranicza narodowościowego w Mołdawii, pokaz, Ministerstwo Kultury i Dziedzictwa Narodowego, Departament Dziedzictwa Kulturowego.

Leontjew P., 1967, Parki Moldavii, Kišinev.

Luniak M, Węgrzynowicz A., 2019, Wpływ renowacji parków miejskich na ich awifaunę lęgowaprzykład z Warszawy, Chrońmy Przyrodę Ojczysta, 75, 1, s. 3-15.

Kravčuk O.P.,1972, Zapovednye i rekomenduemye $k$ zapovedenû cennye raspisnye obekty $v$ raenah Srednego Pridnestovâ, Ohrona prirody Moldavii, 10. 
Michałowski A., Werner B., 2014, Wstępne wytyczne konserwatorskie w sprawie rewaloryzacji i zagospodarowania założenia dworsko-parkowego "Willa Mindic" w Mołdawii. Praca zlec. Fundacja Dziedzictwa Kulturowego, Warszawa.

Monitorul Oficialal. Republicii Moldova, 18, 20 martie 1997, MOLDPRES.

Ozimkowska L., Wojtatowicz J., Jancelewicz R., 2014, Prace rewaloryzacyjne przy ogrodzie Vila Mindyc Mołdawia (Vila Mîndîc, Moldova). Inwentaryzacja drzewostanu. Praca zlec. Fundacja Dziedzictwa Kulturowego, Warszawa.

Ozimkowska L., Wojtatowicz J. Szczepanik A., 2015, Prace rewaloryzacyjne przy ogrodzie Vila Mindyc, Mołdawia (Vila Mîndîc, Moldova) - etap II, ekspertyza wykonana na zlecenie Fundacji Dziedzictwa Kulturowego, Warszawa.

Ozimkowska L., Wojtatowicz J., 2016, Zespót dworsko-parkowy „Willa Mindic” jako szczególny element w krajobrazie i przemiany jego struktury jako znaków czasu, MAZOWSZE Studia Regionalne, 18, Mazowieckie Biuro Planowania Regionalnego, Warszawa, s. 49-69.

Ozimkowska L., Wojtatowicz J., 2020, Metoda waloryzacji drzew ze względu na ich wartości biocenotyczne, MAZOWSZE Studia Regionalne, 32, Mazowieckie Biuro Planowania Regionalnego, Warszawa, s. 123-136.

Pasport pamâtniki istorii i kultury SSSR.

Pepko J., 2008, Skutki przyrodnicze modernizacji parku Kepa Potocka w Warszawie, Turystyka i Rekreacja, 4, s. 29-36.

Soloveva T., 2002, Tainy Villi Myndyk, Novoe vremâ 28 iûnâ 2002, 24.

Taras Â. N., 1986, Pamâtniki arhitektury Moldavii (XVI- načalo XX veka).

Theodorowicz L., 1925, Nieco o heraldyce i rodach Ormian polskich, nakładem autora, Lwów.

Wojtatowicz J., 1994, Avifauna miejskich parków historycznych [w:] Materiały Sympozjum: Dziedzictwo miejskich ogrodów i krajobrazu historycznego, Katedra Urządzania i Pielęgnacji Krajobrazu SGGW, Ośrodek Ochrony Zabytkowego Krajobrazu, Warszawa Ursynów.

Wojtatowicz J., 2010, Ocena drzew szczególnych w krajobrazie [w:] B. Szulczewska, M. Szumański (red.), Horyzonty Architektury Krajobrazu. Metoda architektury krajobrazu, SGGW w Warszawie, Urząd Miasta Stołecznego Warszawy. Wyd. „Wieś Jutra”, Warszawa.

www.brueldelmar.fr / fr/project/ 22 / parc-ecologique-de-saint-jacques [dostęp 28.02.2021 r.]. www.dziedzictwo.org/Działalność/ zespół-dworsko-parkowy-vila-mindic-moldawia [dostęp 28.02.2021 r.]. 


\title{
Application of the biocenotic tree assessment method in the "Vila Mîndîc" park (Moldova) for the implementation of the conceptual land-use project - a case study
}

\begin{abstract}
The article presents the aplication of the biocenotic tree assessment method in the "Vila Mîndîc" park (Moldova). While conducting the inventory, preliminary design decisions were taken into account, which also influenced the determination of tree values. By extending the plant valorization to the study of health, including safety for humans, the results were obtained to carry out the project. Particular areas were selected, which regardless of the conditions, must ensure safe stay; parts of the area where visiting the park is restricted and those where, due to high biocenotic values (including protection of animal breeding and nesting sites) communication routes and leisure areas are not planned. On the basis of the research, areas of exceptional importance for animals were identified and a conceptual land-use project was carried out to accommodate human recreational needs.
\end{abstract}

Key words: landscape architecture, dendrology, biocenotic values of trees, natural connections

\footnotetext{
Lidia Ozimkowska, dr inż. arch. kraj. absolwentka Szkoły Głównej Gospodarstwa Wiejskiego w Warszawie. W latach 1982-1999 zatrudniona w Ogrodzie Botanicznym Polskiej Akademii Nauk w Warszawie - Powsinie na stanowisku projektanta, od 1995 r. współwłaścicielka pracowni projektowej Aster-Park, w latach 1995-2000 współpracowała z czasopismami „Kwietnik” i „Ogrody”, od 1999 pracuje jako nauczyciel akademicki w Wyższej Szkole Ekologii i Zarzq̨dzania w Warszawie, autorka monografii "Granice obiektów architektury krajobrazu", promotor kilkudziesięciu prac dyplomowych, członek SARP, PTD, rzeczoznawca NOT-SITO. Wyższa Szkoła Ekologii i Zarządzania, Warszawa, ul. Olszewska 12; e-mail: l.ozimkowska@gmail.com.

Lidia Ozimkowska, PhD, Engineer of Landscape Architecture. Graduate of the Warsaw University of Life Sciences (SGGW). Landscape designer of the Botanical Garden of the Polish Academy of Sciences in Powsin (1982-1999). Co-owner of the Aster-Park design studio since 1995. In the years 1995-2000 she collaborated with magazines: "Kwietnik"("Flower-bed") and "Ogrody"("Gardens") magazines. An academic teacher at the University of Ecology and Management in Warsaw since 1999. Author of the monograph entitled "Boundaries of Landscape Architectural Objects". Supervisor of several dozen diploma works. Member of the Association of Polish Architects (SARP) and the Polish Dendrology Society (PTD). NOT-SITO Appraiser (the Scientific and Technical Association of Horticultural Engineers and Technicians). University of Ecology and Management, Warszawa, Olszewska 12; e-mail: l.ozimkowska@gmail.com.
}

Jerzy Wojtatowicz, dr inż. arch. kraj. absolwent i wieloletni pracownik naukowy Katedry Architektury Krajobrazu Szkoły Głównej Gospodarstwa Wiejskiego w Warszawie. Od 1997 r. pracownik Wyższej Szkoły Ekologii i Zarządzania w Warszawie, (w latach 2000-2014 Dziekan Wydziału Architektury), od 1995 r. współwłaściciel pracowni projektowej Aster-Park, współautor ksią̇ki „Ptaki w ogrodzie”, redaktor naukowy książek: „Warszawska Przyroda. Obszary i obiekty chronione”, "Przyroda Warszawy” oraz współautor rozdziału "Zespoły przyrodniczo-krajobrazowe i tereny użytku ekologicznego" w monografii „Przyroda Bielan warszawskich". Wyższa Szkoła Ekologii i Zarzadzania, Warszawa, ul. Olszewska 12; e-mail:jerzy.wojtatowicz@gmail.com.

Jerzy Wojtatowicz, PhD, Engineer of Landscape Architecture. Graduate and long-time academic staff member of the Department of Landscape Architecture at the Warsaw University of Life Sciences (SGGW). Since 1997 he has been associated with the University of Ecology and Management in Warsaw, where he served as the Dean of the Faculty of Architecture between 2000 and 2014. He has also been running the Aster-Park design studio together with Lidia Ozimkowska since 1995. Co-author of 'Ptaki w ogrodzie' (Birds in Your Garden) and a chapter on natural and landscape complexes and lands used for environmental purposes in a monograph entitled 'Przyroda Bielan warszawskich' (Nature in the Warsaw District of Bielany). Science editor of two book publications: 'Warszawska Przyroda. Obszary i obiekty chronione' (Warsaw's Nature. Sites and Areas Under Protection) and 'Przyroda Warszawy' (Nature in Warsaw). University of Ecology and Management, Warszawa, Olszewska 12; e-mail:jerzy.wojtatowicz@gmail.com. 